\title{
A phase I study of hydralazine to demethylate and reactivate the expression of tumor suppressor genes
}

Pilar Zambrano ${ }^{\dagger 1}$, Blanca Segura-Pacheco ${ }^{\dagger 1}$, Enrique Perez-Cardenas ${ }^{1}$, Lucely Cetina² ${ }^{2}$ Alma Revilla-Vazquez ${ }^{3}$, Lucía Taja-Chayeb ${ }^{1}$, Alma ChavezBlanco $^{1}$, Enrique Angeles ${ }^{4}$, Gustavo Cabrera1, Karina Sandoval ${ }^{3}$, Catalina Trejo-Becerril ${ }^{1}$, Jose Chanona-Vilchis ${ }^{1}$ and Alfonso DuenasGonzález*1

\begin{abstract}
Address: ${ }^{1}$ Unidad de Investigación Biomédica en Cáncer, Instituto Nacional de Cancerología/Instituto de Investigaciones Biomédicas, UNAM, Mexico, ${ }^{2}$ Division of Clinical Research, Instituto Nacional de Cancerología, Mexico, ${ }^{3}$ Laboratorio de Desarrollo de Métodos Analíticos, FESCuautitlán, UNAM, Mexico and ${ }^{4}$ Laboratorio de Química Medicinal FES-Cuautitlán, UNAM, Mexico

Email: Pilar Zambrano - pila_55@yahoo.com; Blanca Segura-Pacheco - ba0512@prodigy.net.mx; Enrique Perez-

Cardenas - zperez@salud.gob.mx; Lucely Cetina - micuentalucely@yahoo.com; Alma Revilla-Vazquez - almarv@servidor.unam.mx; Lucía TajaChayeb - chayeb@salud.gob.mx; Alma Chavez-Blanco - celular_alma@hotmail.com; Enrique Angeles - angeles@servidor.unam.mx;

Gustavo Cabrera - gus_cabrera@yahoo.com; Karina Sandoval - ksandoval@yahoo.com.mx; Catalina Trejo-Becerril - ctrejobecerril@yahoo.com; Jose Chanona-Vilchis - jchanonav@incan.edu.mx; Alfonso Duenas-González* - alfonso_duenasg@yahoo.com

* Corresponding author †Equal contributors
\end{abstract}

Published: 29 April 2005

BMC Cancer 2005, 5:44 doi:10.1 I86/147I-2407-5-44

This article is available from: http://www.biomedcentral.com/147I-2407/5/44

(c) 2005 Zambrano et al; licensee BioMed Central Ltd.

This is an Open Access article distributed under the terms of the Creative Commons Attribution License (http://creativecommons.org/licenses/by/2.0), which permits unrestricted use, distribution, and reproduction in any medium, provided the original work is properly cited.
Received: 25 January 2005

Accepted: 29 April 2005

\begin{abstract}
Background: The antihypertensive compound hydralazine is a known demethylating agent. This phase I study evaluated the tolerability and its effects upon DNA methylation and gene reactivation in patients with untreated cervical cancer.

Methods: Hydralazine was administered to cohorts of 4 patients at the following dose levels: I) $50 \mathrm{mg} / \mathrm{day}$, II) 75 $\mathrm{mg} /$ day, III) $100 \mathrm{mg} /$ day and IV) $150 \mathrm{mg} /$ day. Tumor biopsies and peripheral blood samples were taken the day before and after treatment. The genes APC, MGMT; ER, GSTPI, DAPK, RAR $\beta$, FHIT and pl 6 were evaluated pre and post-treatment for DNA promoter methylation and gene expression by MSP (Methylation-Specific PCR) and RT-PCR respectively in each of the tumor samples. Methylation of the imprinted HI9 gene and the "normally methylated" sequence clone I.2 was also analyzed. Global DNA methylation was analyzed by capillary electrophoresis and cytosine extension assay. Toxicity was evaluated using the $\mathrm{NCl}$ Common Toxicity Criteria.

Results: Hydralazine was well tolerated. Toxicities were mild being the most common nausea, dizziness, fatigue, headache and palpitations. Overall, $70 \%$ of the pretreatment samples and all the patients had at least one methylated gene. Rates of demethylation at the different dose levels were as follows: $50 \mathrm{mg} / \mathrm{day}, 40 \% ; 75 \mathrm{mg} / \mathrm{day}$, $52 \%, 100 \mathrm{mg} /$ day, $43 \%$, and $150 \mathrm{mg} /$ day, $32 \%$. Gene expression analysis showed only 12 informative cases, of these 9 (75\%) re-expressed the gene. There was neither change in the methylation status of HI9 and clone I.2 nor changes in global DNA methylation.
\end{abstract}

Conclusion: Hydralazine at doses between 50 and $150 \mathrm{mg} /$ day is well tolerated and effective to demethylate and reactivate the expression of tumor suppressor genes without affecting global DNA methylation 


\section{Background}

Cancer is considered to be a disease of the genome that results from a plethora of genetic and epigenetic lesions. Among the epigenetic alterations, DNA hypermethylation is thought to play an important role in tumor development and progression [1]. In this regard, at least three functional DNA methyltransferases (DNMTs) have been identified, the most abundant is DNMT1 which preferentially methylates hemi-methylated DNA [2], and plays a key role in imprinting and X-chromosome inactivation during embryogenesis $[3,4]$. DNTM1 localizes to replication foci [5], at least in part by interacting with proliferating cell nuclear antigen (PCNA), a protein closely involved in DNA replication. It is therefore responsible for maintaining proper methylation levels during replication and possibly repair [6]. Other known functional methyltransferases are DNMT3a and DNMT3b, which are responsible for de novo methylation during embryogenesis [7]. DNMT3a and DNMT3b have equal preferences for hemi-methylated and non-methylated DNA, and so have been classified as de novo methyltransferases [8]. DNA methylation can directly interfere with transcriptional factor binding and thus inhibit replication [9], with methylCpG binding proteins which bind methylated DNA and with regulatory proteins that inhibit transcription [10]. In addition, both DNMT1 and methyl-binding proteins (MBP), such as methyl-CpG-binding protein 2 (MeCP2) recruit histone deacetylases which deacetilate histone core tails leading to tighter chromatin packaging, reducing the access of transcriptional factors to DNA $[11,12]$.

Cancer cells are considered to have global hypomethylation and regional hypermethylation. Hypermethylated regions are $\mathrm{CpG}$ islands, $\mathrm{CpG}$ and $\mathrm{GpC}$ rich sequences 1 $\mathrm{kb}$ long found proximal to gene promoters involved in transcriptional control [13]. These islands are associated with roughly half of all genes [15], their methylation can repress transcription in a manner analogous to a mutation or deletion (16). It is thought that tumor suppressor gene promoter hypermethylation contributes to their transcriptional silencing [14]. Furthermore, there is a growing list of tumor suppressor genes in both sporadic and familial cancers which are found to be transcriptionally silenced by hypermethylation [17].

In this regard, tumor suppressor gene transcriptional reactivation through promoter de-methylation represents an attractive strategy for anticancer treatment. Substantial preclinical studies characterizing DNA methylation inhibitors have shown cancer cell line growth arrest in vitro and antitumor effects in animal models, including survival prolongation [18-20]. These concepts are supported by the transforming effect of exogenous DNA methyltransferase gene expression observed in fibroblasts [21] as well as by the malignant phenotype reversion documented using antisense oligonucleotides against this gene [22]. These findings have paved the way for the clinical testing of demethylating agents in cancer.

Nucleoside deoxycytidine analogs formerly known as classic cytotoxic agents and later known as DNA methylation inhibitors show poor activity against solid tumors [23] however, 5-aza-2'-deoxycytidine has recently gained considerable attention and is presently being tested as a demethylating agent for the treatment of hematological neoplasms [24]. MG98, is an antisense oligodeoxynucleotide directed against the 3 ' untranslated region of the DNA methyltransferase-1 enzyme mRNA that has been tested in clinic [23]. A phase I study using biweekly administration of this agent, showed no consistent decrease of mRNA levels in the peripheral blood cells of patient [25]. Although this agent has shown activity in xenografts models of nude mice, demonstration of antitumor efficacy in humans is pending.

Our group has recently shown in vitro and in vivo promoter demethylation and tumor suppressor gene transcriptional reactivation mediated by the antihypertensive compound hydralazine [26]. Its DNA demethylating activity can be explained by the interaction between its Nitrogen atoms with residues Lys162 and Arg240 of the DNA methyltransferase active site as showed in a silico model [27]. Hydralazine is a well-tolerated drug devoid of the common side effects of cytotoxic chemotherapy agents, however, its hypotensive effects could limit its use in a clinical setting, we thus felt desirable to determine the dose at which its demethylating activities were observed in a set of genes known to be methylated in cervical cancer.

\section{Methods \\ Patient selection}

Previously untreated patients with histological diagnosis of carcinoma of the cervix were entered into this phase I study. The following inclusion criteria were applied: 1) age between 18 and 75 years; 2) Karnofsky status $70 \%$ or higher; 3) hematological, renal and hepatic functions as follows: hematological: Hemoglobin equal or higher than $10 \mathrm{~g} / \mathrm{L}$, leukocytes $>4000 / \mathrm{mm}^{3}$, platelets $>100000 / \mathrm{mm}^{3}$, total bilirubin and transaminases $<1.5 \times$ the normal upper limit, and normal serum creatinine; 4 ) a normal chest Xray and 5) signed informed consent. Exclusion criteria were: 1) history of allergy to hydralazine; 2) any past or current cardiovascular condition (higher blood pressure, heart failure, etc., that required pharmacological treatment; 3) any past or current rheumatic or autoimmune disease; 4) uncontrolled infection or other systemic diseases; 5) concomitant treatment with any experimental drug; 6) pregnant or nursing women; 7) mental illness; and 8) previous or concomitant malignant diseases other 
than non-melanoma skin cancer. The Institutional Regulatory Board approved the study protocol.

\section{Clinical samples and nucleic acids extraction}

Biopsies were taken from areas with visible macroscopic cervical tumor using a sterile biopsy punch the day before and the day after the 10 days of hydralazine treatment. The specimen was immediately frozen at $-20^{\circ} \mathrm{C}$ for further processing. In addition, a blood sample of $10 \mathrm{~mL}$ was drawn from the arm by venipuncture for subsequent mononuclear cell DNA extraction. In addition, the surgical specimen of an early stage cervical cancer patient undergoing radical hysterectomy was multi-sampled in the surgical room by taking 4 small fragments of the macroscopic tumor from separate areas. Genomic DNA was isolated from the tumor tissues and from the buffy coat layer of blood samples using the standard method of proteinase $\mathrm{K}$ digestion and phenol-chloroform extraction. RNA from tumor biopsies was obtained using the TriReagent (Gibco BRL Grand Island, New York) RNA extraction kit following the manufacturer instructions.

\section{Hydralazine treatment}

Twenty four hours after tumor and blood sampling patients where divided into the following groups and started on oral hydralazine for a ten day period: I) $25 \mathrm{mg}$ every 12 hours, II) $25 \mathrm{mg}$ every 8 hours; III) $50 \mathrm{mg}$ every 12 hours; and IV) $50 \mathrm{mg}$ every 8 hours. Toxicity was assessed at the end of study period (10 days), with special emphasis on the presence, throughout the treatment days, of known signs and symptoms associated with hydrala- zine treatment (hypotension, tachycardia, palpitations, syncope, sweating, headache, dizziness and fluid retention). The study period ended at day ten and patients went to receive definitive treatment.

\section{Analysis of DNA methylation in the tumor}

The methylation status of genes was determined in the biopsies pre and post-treatment. The gene set studied was: p16, RAR $\beta$, MGMT, ER, FHIT, APC, DAPK and GSTp1 which were analyzed by methylation-specific PCR as previously described [28]. In addition, the four fragments of the tumor of the untreated patient were analyzed for methylation of the DAPK gene. Briefly, $1 \mu \mathrm{g}$ of DNA in a volume of $100 \mu \mathrm{l}$ of each sample was denaturated with freshly prepared $\mathrm{NaOH}$ at a final concentration of $0.2 \mathrm{M}$, and modified according to the manufacturer instructions of the DNA Modification kit (Intergen, Purchase, New York). The PCR mixture contained $2 \mu \mathrm{l}$ of 10X PCR buffer, $0.5 \mathrm{U}$ of Taq Gold polymerase, dNTPs (each $1.25 \mathrm{mM}$ ), $300 \mathrm{ng}$ of primers and bisulfite-modified DNA in a final volume $20 \mu \mathrm{l}$. Products were visualized in a $2 \%$ agarose gel under UV light. The primers and conditions for PCR are shown in Table 1. A gene was deemed methylated whenever a band was present after amplification with the methylated, or both methylated and unmethylated set of primers. On the contrary, a gene was deemed unmethylated when a band was present after amplification with the unmethylated set in the absense of band with the methylated set. An exception to these criteria was when in the pretreatment biopsy there was only a methylated band but both unmethylated and methylated bands after

Table I: Primers and conditions used for MSP.

\begin{tabular}{|c|c|c|c|c|}
\hline Primer set & Sense 5'-- 3' & Antisense 5'--- 3' & Size & Annealing \\
\hline pl6M & TTATTAGAGGGTGGGGCGGATCGC & GACCCCGAACCGCGACCGTAA & 150 & $62^{\circ} \mathrm{C}$ \\
\hline pl6 U & TTATTAGAGGGTGGGGTGGATTGT & CAACСCCAAACCACAACCATAA & $|5|$ & $62^{\circ} \mathrm{C}$ \\
\hline RAR $\beta M$ & TCGAGAACGCGAGCGATTCG & GACCAATCCAACCGAAACGA & 146 & $55.5^{\circ} \mathrm{C}$ \\
\hline RAR $\beta U$ & TTGAGAATGTGAGTGATTTGA & AACCAATCCAACCAAAACAA & 146 & $55.5^{\circ} \mathrm{C}$ \\
\hline MGMT M & TTTCGACGTTCGTAGGTTTTCGC & AACCAATCCAACCAAAACAA & 81 & $55.7^{\circ} \mathrm{C}$ \\
\hline MGMT U & TTTGTGTTTTGATGTTTGTAGGTTT & ААСТССАСАСТСТТССАААAАС & 93 & $55.7^{\circ} \mathrm{C}$ \\
\hline FHIT M & TTGGGGCGCGGGTTTGGGTTTTTAA & CGTAAACGACGCCGACCCCACTA & 74 & $55.5^{\circ} \mathrm{C}$ \\
\hline FHIT U & TTGGGGTGTGGGTTTGGGTTTTTA & CATAAACAACACCAACCCCACTA & 74 & $55.5^{\circ} \mathrm{C}$ \\
\hline DAPK M & GGATAGTCGGATCGAGTTAACGT & СССТСССАAACGCCGA & 98 & $55.7^{\circ} \mathrm{C}$ \\
\hline DAPK U & GGAGGATAGTTGGATTGAGTTAAT & CAAATCССТСССAAACACCAA & 106 & $55.7^{\circ} \mathrm{C}$ \\
\hline APC M & TATTGCGGAGTGCGGGTC & TCGACGAACTCCCGACGA & 100 & $56^{\circ} \mathrm{C}$ \\
\hline APC U & GTGTTTTATTGTGGAGTGTGGGTT & ССAATCAACAAACTCCСAACAA & 110 & $56^{\circ} \mathrm{C}$ \\
\hline GSTpI M & TTCGGGGTGTAGCGGTGGTC & GCCCCAATACTAAATCACGACG & 91 & $56^{\circ} \mathrm{C}$ \\
\hline GSTPI U & GATGTTTGGGGTGTAGTGGTTGTT & CCACCCCAATACTAAATCACAACA & 97 & $56^{\circ} \mathrm{C}$ \\
\hline HI9M & TTATAAAATCGAAAATTACGCGCGA & AGATGATTTTCGTGAATTTTGCG & 136 & $55^{\circ} \mathrm{C}$ \\
\hline $\mathrm{HI} \mathrm{U}$ & TATAATTATAAAATCAAAAATTACA & TTTTAGATGATTTTTGTGAATTTT & 145 & $55^{\circ} \mathrm{C}$ \\
\hline ER M & CGGTTGGAGTTTTTGAATCGTTC & CTAGCGTTAACGACGACCG & $|5|$ & $55^{\circ} \mathrm{C}$ \\
\hline ER U & ATGAGTTGGAGTTTTTGAATTGTTT & ATAAACCTACACATTAACAACAACCA & 158 & $55^{\circ} \mathrm{C}$ \\
\hline Clone $1.2 \mathrm{M}$ & ATGAGTTGGAGTTTTTGAATTGTTT & AATAATAAACGTAACGCCCGCGAAC & 258 & $63^{\circ} \mathrm{C}$ \\
\hline Clone $1.2 \mathrm{U}$ & GGTTGTTTGGTTTTTATTGGGATGTTTTT & ССТАААТАAТАААСАТААСАСССАСАAАС & 258 & $63^{\circ} \mathrm{C}$ \\
\hline
\end{tabular}


Table 2: Primers and conditions used for RT-PCR

\begin{tabular}{|c|c|c|c|c|}
\hline Primer set & Sense 5'-- 3' & Antisense 5'--- 3' & Size & Annealing \\
\hline p16 & AGCCTTCGGCTGACTGGCTGG & CTGCCCATCATCATGACCTGG & 150 & $60^{\circ} \mathrm{C}$ \\
\hline RAR $\beta$ & GACTGTATGGATGTTCTGTCAG & ATTTGTCCTGGCAGACGAAGCA & 146 & $50^{\circ} \mathrm{C}$ \\
\hline MGMT & GCTGCAGACCAVCTCTGTGGCACG & GCCGCCTCTTCACCATCCCG & 81 & $50^{\circ} \mathrm{C}$ \\
\hline FHIT & ATGTCGTTCAGATTTGGCCAAC & TCATAGATGCTGTCATTCCTGT & 340 & $53^{\circ} \mathrm{C}$ \\
\hline DAPK & ААСССАТСАТССАТGССАТС & TCTCTCCTTCTCGGTTCTTGA & 200 & $51^{\circ} \mathrm{C}$ \\
\hline APC & GAGACAGAATGGAGGTGCTGC & GTAAGATGATTGGAATTATCTTCT & 180 & $56^{\circ} \mathrm{C}$ \\
\hline GSTpI & TCCGCTGCAAATACATCTCC & TGTTTCCCGTTGCCATTGAT & 320 & $50^{\circ} \mathrm{C}$ \\
\hline ER & GGAGACATGAGAGCTGCCAAC & CCAGCAGCATGTCGAAGATC & 480 & $55^{\circ} \mathrm{C}$ \\
\hline
\end{tabular}

treatment.

\section{Analysis of DNA methylation in mononuclear cells of peripheral blood}

The methylation status of the imprinted H19 gene as well as the clone 1.2 which is known to be normally methylated and not subjected to imprinting [29] was also analyzed by methylation specific PCR. The positive control for unmethylation in the clone 1.2 sequence was DNA from cultured cells treated with ethionine. Primers and conditions are shown in Table 1.

\section{Analysis of gene expression}

Total RNA obtained from pre and post-treatment biopsies was reverse transcribed using a RT-PCR kit (Perkin Elmer; Branchburg, New Jersey) following the manufacturer instructions. Primers and conditions for amplifications are shown in Table 2.

\section{Quantification genomic 5-methylcytosine DNA content by capillary electrophoresis}

Adenine, thymine, guanine, uracyl, cytosine and 5methyl-cytosine were purchased from Sigma (St. Louis, $\mathrm{MO}$; USA). Bases were dissolved at $2.4 \mathrm{mM}$ in $0.1 \mathrm{M} \mathrm{HCL}$, $0.01 \mathrm{M} \mathrm{HCL}$, or Milli-Q-grade water (Millipore, Bedford, $\mathrm{MA}$ ) and filtered through $0.45 \mu \mathrm{m}$ pore size filters (Millipore). Briefly, extracted DNA samples were resuspended in TE buffer at $(1 \mu \mathrm{g} / \mu \mathrm{l})$. Hydrolysis of DNA was carried out by incubating $40 \mu \mathrm{g}$ of DNA in $2 \mathrm{~mL} 88 \% \mathrm{v} / \mathrm{v}$ formic acid at $140^{\circ} \mathrm{C}$ into a sealed ampoule for $90 \mathrm{~min}$. After hydrolysis, samples were reduced to dryness by speedvac concentration and redissolved in $30 \mu \mathrm{L}$ of Milli-Q-grade water. DNA samples of pre and post-treatment biopsies were analyzed for 5-methylcytosine content by capillary electrophoresis (CE) as reported by us [30]. For the CE procedure, an uncoated fused-silica capillary (BeckmanCoulter; $60 \mathrm{~cm} \times 75 \mu \mathrm{m}$; effective length, $44.5 \mathrm{~cm}$ ) was used in a CE system (P/ACE MDQ; Beckman-Coulter) connected to a data-processing station (32 Karat software). The running buffer was $20 \mathrm{mM} \mathrm{NaCO}_{3}$ (pH $9.6 \pm$ 1) containing $80 \mathrm{mM}$ SDS. Running conditions were $25^{\circ} \mathrm{C}$ with an operating voltage of $20 \mathrm{kV}$. On-column absorbance was monitored at $223 \mathrm{~nm}$. Before each run, the capillary system was conditioned by washing with the running buffer for $2 \mathrm{~min}$. Buffers and washing solutions were prepared with Milli-Q water and filtered throughout $0.45-\mu \mathrm{m}$ filters. Hydrolyzed samples, previously filtered through $0.45 \mu \mathrm{m}$ pore filters, were injected under pressure ( 0.5 p.s.i.) for $15 \mathrm{~s}$. The relative methylation of each DNA sample was taken as the percentage of ${ }^{\mathrm{m}} \mathrm{C}$ in total cytosine: ${ }^{\mathrm{m}} \mathrm{C}$ peak area $\times 100 /\left(\mathrm{C}\right.$ peak area $+{ }^{\mathrm{m}} \mathrm{C}$ peak area $)$.

\section{Methylation pattern in global DNA}

Global DNA methylation was evaluated by the cytosineextension assay [31] which is based on the use of methylation-sensitive restriction endonuclease that leave a $5^{\prime}$ guanine overhang after DNA cleavage, with subsequent single nucleotide extension with radiolabeled [(3)H]dCTP. Briefly $1 \mu \mathrm{g}$ of DNA from tumor tissue was digested overnight with BssHII according to the manufacturer. Single nucleotide extension reaction was performed in a $25 \mu \mathrm{l}$ reaction mixture containing $0.25 \mu \mathrm{g}$ of DNA, $1 \mathrm{X}$ buffer II, $1 \mathrm{mM} \mathrm{MgCl}, 0.25 \mathrm{U}$ of DNA polymerase (Perkin Elmer; Branchburg, New Jersey $\left[{ }^{3} \mathrm{H}\right] \mathrm{dCTP}(\mathrm{Ci} / \mathrm{mmol})$ and incubated at $56^{\circ} \mathrm{C}$ for 1 hour, then placed on ice. The reaction mixture was then applied to sephadex G25 column. For the column chromatography, each sephadex G25 column was centrifuged for $10 \mathrm{sec}$., at $5000 \mathrm{rpm}$ to remove the buffer and loaded with the reaction mixture. After loading the samples to the column, the radiolabeled DNA was collected by centrifugation of the column and mixed with liquid scintillation for the determination of radioactivity. Results were expressed as the percentage change from the average controls which were tumor samples of patients pre and post-treatment without BssHII digestion.

\section{Results}

\section{Study group}

A total of 16 patients were studied. All of them were chemotherapy or radiation naive and had a macroscopic tumor accessible for punch biopsy. Their mean age was 51.8 (35-75 years), all cases were squamous histology and 
Table 3: Clinical characteristics of patients

\begin{tabular}{|c|c|}
\hline Number & 16 \\
\hline Mean Age & 51.8 (35-75 years) \\
\hline \multicolumn{2}{|l|}{ Histology } \\
\hline Squamous & $16(100 \%)$ \\
\hline \multicolumn{2}{|l|}{ FIGO Stage* } \\
\hline IIB & $8(50 \%)$ \\
\hline IIIB & $8(50 \%)$ \\
\hline \multicolumn{2}{|l|}{ Performance Status** } \\
\hline 0 & $10(62 \%)$ \\
\hline I & $6(38 \%)$ \\
\hline
\end{tabular}

*International Federation of Gynecology and Obstetrics,

** World Health Organization Criteria

Table 4: Toxicity to hydralazine expressed by number of patients suffering the event ( 16 patients)

\begin{tabular}{lcccc}
\hline \multicolumn{1}{c}{ Toxicity } & \multicolumn{5}{c}{ 4 Patients in each dose level $(\mathrm{mg}$} \\
\hline & 50 & 75 & 100 & 150 \\
Nausea & $2 / 4$ & - & $2 / 4^{*}$ & $2 / 2$ \\
Vomiting & - & - & - & - \\
Dizziness & - & $1 / 4^{*}$ & $1 / 4$ & - \\
Fatigue & $2 / 4$ & $2 / 4$ & $3 / 4$ & $1 / 4$ \\
Flushes & - & - & - & - \\
Headache & $2 / 4$ & $1 / 4$ & $3 / 4$ & $2 / 4$ \\
Edema & - & - & - & - \\
Palpitations & $1 / 4$ & $2 / 4$ & $2 / 4$ & $3 / 4$ \\
\hline
\end{tabular}

* Grade 2 toxicity. All other were grade I.

staged as FIGO stage IIB and IIIB. The status performance was $0-1$ in all patients (Table 3 ).

\section{Treatment compliance and side effects}

All patients completed the prescribed medication and reported that hydralazine treatment was well tolerated. Side effects as evaluated by the Common Toxicity Criteria are showed in Table 4. Grade 1 fatigue, headache and palpitations were observed in 50\% of patients; grade 1 nausea was present in $37 \%$ of cases, being grade 2 in only one patient. Only 2 out of 16 patients presented dizziness grades 1 and 2 respectively. No patient stopped treatment due to adverse effects. We observed no side-effect dose relationship.

\section{Gene promoter methylation}

Methylation analysis of the biopsies taken before and after 10 days of hydralazine administration was performed in all 16 patients. Methylation results involving the genes analyzed were variable. Overall, $70 \%$ ( 89 out of 128 ) of the pretreatment samples analyzed ( 8 genes for each of the 16 pre-treatment biopsies) had at least one methylated gene, and all 16 patients had at least one methylated gene. Analysis by individual genes showed the following rates of methylated genes: APC (94\%), ER (25\%) FHIT (88\%), GSTp1 (88\%), MGMT(81\%), p16(19\%), RAR $\beta(62 \%)$, and DAPK (100\%), irrespective of the dose of hydralazine used, the post-treatment biopsies showed a variable demethylation rate according to the gene, varying from $15 \%(2 / 13$ samples) for the MGMT gene, to $67 \%$ of demethylation for the p16 gene (2 out of 3 samples), (Figure 1A). Representative cases of the results are shown in Figure 1B. Correlation between demethylation analysis and dose level revealed the following results: at $50 \mathrm{mg}$ a day, $40 \%$ of methylated genes suffered demethylation; at $75 \mathrm{mg}$ it was $52 \%$, at $100 \mathrm{mg}$ dose the rate was $43 \%$, and $32 \%$ for the $150 \mathrm{mg}$ dose (Figure 1C).

\section{Gene expression}

All cases showed expression of $\beta$ actin. Gene expression analysis showed that $90 \%$ (116 out of 128) of the tumor samples expressed the messenger in the pre-treatment and post-treatment biopsies regardless of methylation status, hence were not informative. On the other hand, there were only 12 informative cases. Of these 12 cases, three (25\%) (having only the methylated band pretreatment) showed no re-expression after treatment (2/ DAPK, 1/ GSTp1 cases). These three cases received the $50 \mathrm{mg}$ dose. In the remaining 9 cases $(75 \%)$ expression of the gene was re-induced after treatment. These nine cases behaved as follows: Five cases were RT-PCR negative pretreatment (only methylated band) and converted positive post-treatment, displaying methylated and unmethylated bands (FHIT two cases - 100 and $150 \mathrm{mg}$ doses- MGMT two cases -75 and $150 \mathrm{mg}$ doses, GSTp1 one case $-50 \mathrm{mg}$ dose). Three cases RT-PCR negative pre-treatment with methylated band which converted to unmethylated and expression positive in the post-therapy biopsy (DAPK and ER genes at $75 \mathrm{mg}$, GSTp 1 at $150 \mathrm{mg}$ dose), and finally, a RTPCR negative in the pre-treatment biopsy despite having methylated and unmethylated bands which converted to RT-PCR positive accompanied by only unmethylated band (GSTp1 case at $75 \mathrm{mg}$ ). Table 5, Figure 2D. Three representative cases are shown in Figure 2A, B, C.

\section{Methylation heterogeneity in tumor samples}

Because the sampling of tumor may lead to tissue specimens with different degree of "contamination" with nonmalignant that may affect the result of methylation in the post-treatment, biopsies, all samples were analyzed by a pathologist. The results showed that in all biopsy samples the content of malignant cells varied from 30 to $70 \%$. A representative set is shown in Figure 3A. In addition, we reasoned that if tumor heterogeneity were of a magnitude to yield different methylation patterns in the tumors regardless of the treatment, then multisampling a tumor 

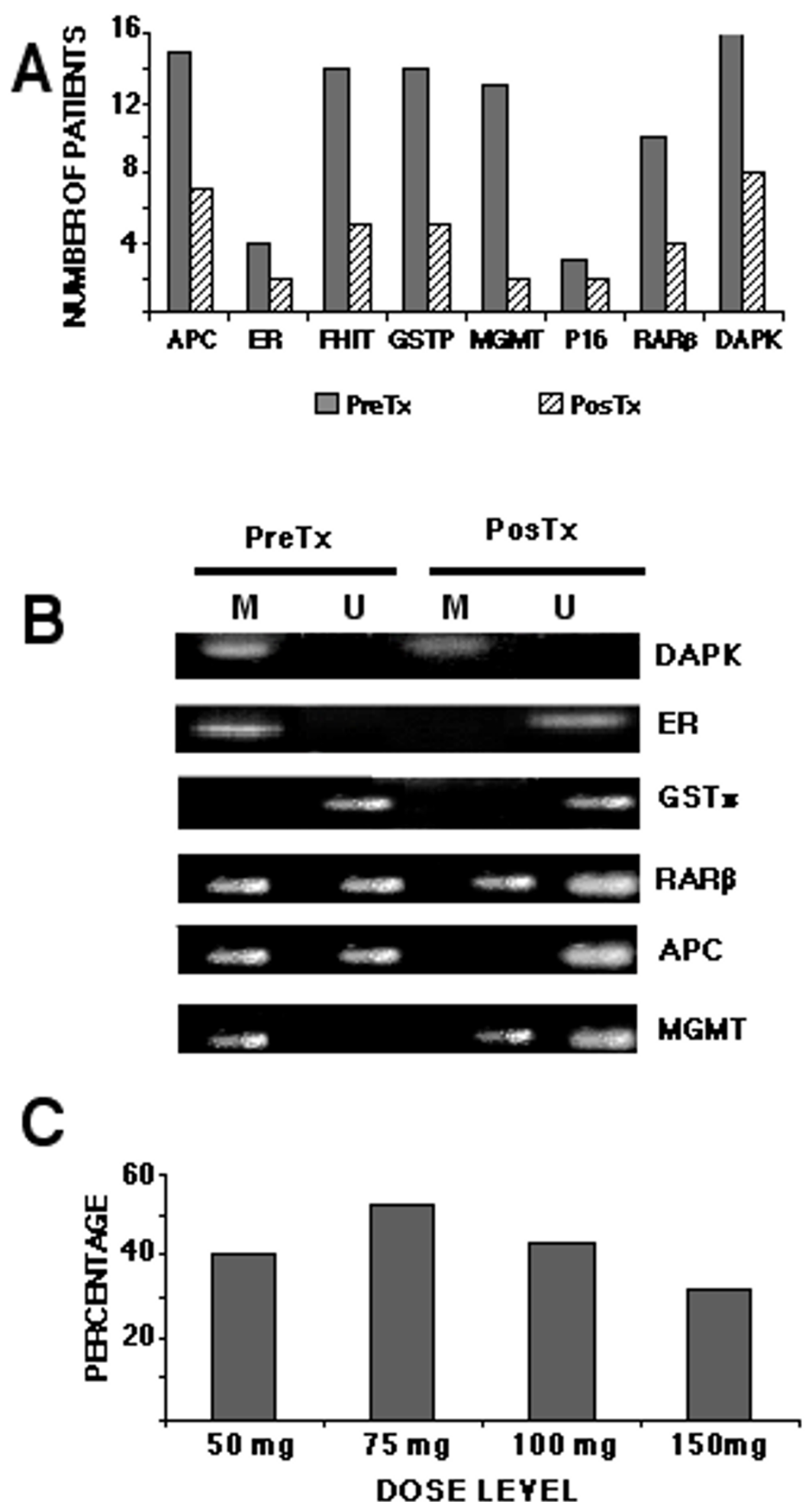

Figure I

IA. Pre- (dark bars) and post-hydralazine treatment (light bars). The bars represent the number of patients that showed methylation for each studied gene from each of the 16 patients. IB. Representative cases of genes ( $M$ methylated, $U$ unmethylated; pre/post): M/M; M/U; U/U, M/U; MU/U; M/ U-M. IC. Percentage of demethylation after treatment according to the dose. Percentage was calculated considering $100 \%$ methylation the total number of pre-treatment methylated genes in each cohort of 4 patients 
Table 5: Methylation and gene re-expression of the 12 informative cases.

\begin{tabular}{|c|c|c|c|c|c|c|}
\hline \multirow[b]{2}{*}{ Gene } & \multirow[b]{2}{*}{ dose level } & \multicolumn{2}{|c|}{ Pre-treat } & \multicolumn{2}{|c|}{ Post-treat } & \multirow{2}{*}{$\begin{array}{c}\text { Re-expression } \\
\text { Yes/No }\end{array}$} \\
\hline & & $M$ & $U$ & $M$ & $\cup$ & \\
\hline DAPK & 50 & + & - & + & - & No \\
\hline DAPK & 50 & + & - & + & - & No \\
\hline GSTPI & 50 & + & - & + & - & No \\
\hline FHIT & 100 & + & - & + & + & Yes \\
\hline FHIT & 150 & + & - & + & + & Yes \\
\hline MGMT & 75 & + & - & + & + & Yes \\
\hline MGMT & 150 & + & - & + & + & Yes \\
\hline GSTPI & 50 & + & - & + & + & Yes \\
\hline DAPK & 75 & + & - & - & + & Yes \\
\hline ER & 75 & + & - & - & + & Yes \\
\hline GSTpI & 150 & + & - & - & + & Yes \\
\hline GSTPI & 75 & + & + & - & + & Yes \\
\hline
\end{tabular}

with subsequent methylation analysis of each of the tumor fragments will render zones with different methylation pattern. The analysis of the surgical specimen of an untreated patient showed that the methylation of the DAPK gene promoter was the same in the four fragments of the tumor. Figure 3B.

\section{Methylation of imprinted and "normally methylated" genes}

The methylation status of the imprinted gene $\mathrm{H} 19$ was investigated in the DNA extracted from peripheral blood cells. As shown in Figure 4, no change in the expected pattern of bands was observed after treatment, all patients showed bands with the methylated and unmethylated set of primers. A consistent pattern of methylation also was observed in all patients analyzed for the "normally methylated" sequence clone 1.2. No case showed demethylation at this locus.

\section{Global methylation}

Global tumor DNA methylation was evaluated by two methods, capillary electrophoresis and cytosine extension. Enough DNA to perform capillary electrophoresis was only available in five cases (four patients taking 100 $\mathrm{mg}$, and one taking $150 \mathrm{mg}$ /day respectively). The relative methylation of each DNA sample was taken as the percentage of $\mathrm{d}^{\mathrm{m}} \mathrm{C}$ in total cytosine. Figure 5A shows the relative methylation in theses cases. Remarkably, relative methylation in all cases was between 34.2 and 38.4\% and there was no change in methylation levels after hydralazine treatment $(37.3 \% \pm 0.81$ and $36.3 \% \pm 1.1$ pre and post-treatment respectively). An electropherogram showing the separation of the analytes of interest, $\mathrm{C}$ and ${ }^{\mathrm{m}} \mathrm{C}$ peak are shown in Figure 5B. In the cytosine extension assay, the extent of $[(3) \mathrm{H}] \mathrm{dCTP}$ incorporation after restriction enzyme treatment is directly proportional to the number of unmethylated (cleaved) $\mathrm{CpG}$ sites. The results of this assay showed no statistically significant changes in the tumor samples pre and post-treatment as the percentage increase in radiolabel incorporation were $15 \% \pm 31.3 \%$ and $7 \% \pm 16.7 \%$ respectively, Figure 5C.

\section{Discussion}

Malignant tumors frequently silence genes that control cell growth, differentiation and apoptosis through DNA methylation at their promoter regions; consequently, their reactivation by DNA methylation inhibitors has raised considerable interest as anti-tumor therapy. The present focus on DNA methylation has opened a new way to clinically test the ability of diverse compounds as tumor suppressor gene transcriptional reactivators. We previously reported that hydralazine induces in vitro and in vivo, demethylation and transcriptional reactivation at the mRNA and protein levels of the ER, RAR $\beta$ and p16 genes [26]. The present study confirms our previous findings in a larger number of patients receiving different hydralazine dosage levels for a 10 day period. Our results demonstrate that hydralazine can demethylate and reexpress tumor suppressor genes in previously untreated cervical cancer patients in all the tested dosages. Theses effects are accompanied by no change in global tumor DNA methylation evaluated by two methods, and lack of demethylation in the imprinted gene $\mathrm{H} 19$ and the "normally methylated" 1.2 clone in peripheral mononuclear blood cells.

Hydralazine, a widely available peripheral vasodilator agent, has been extensively used for high blood pressure, heart failure and pregnancy-associated hypertensive disorders [32-34]. Hence, its evaluation as a demethylating 


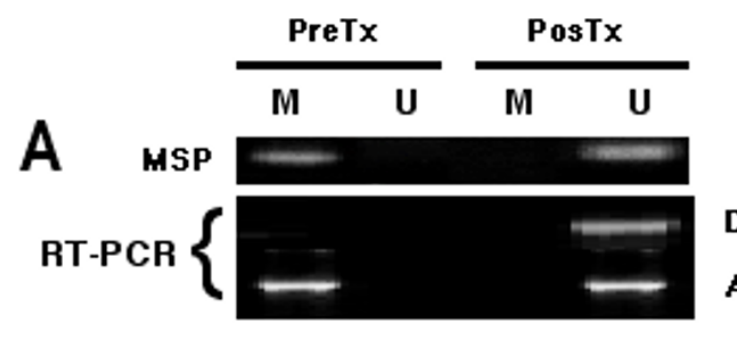

DAPK ACTIN<smiles>[BH3-]</smiles>

HSP RT-PCR \{
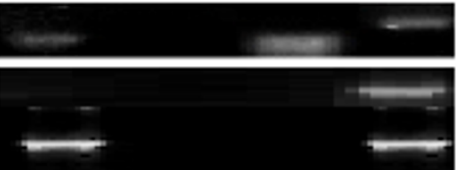

HGHT ACTIN
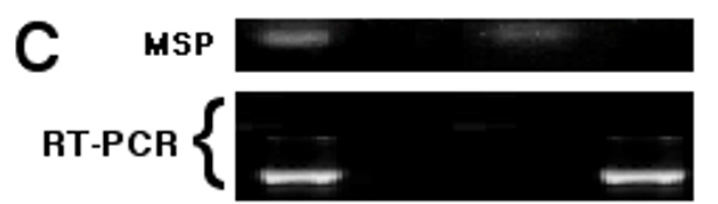

DAPK ACTIN
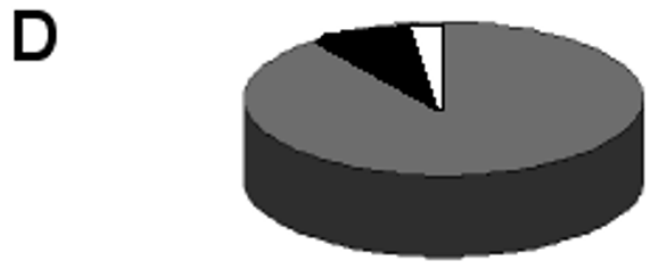

\section{RE-EXPRESSED GENES NO RE-EXPRESSED GENES NON-INFORHATIYE}

\section{Figure 2}

Representative cases correlating methylation and re-expression before and after hydralazine treatment. 2A is a patient treated with $75 \mathrm{mg} /$ day that demethylated and re-expressed the DAPK gene. 2B corresponds to a patient receiving I50 $\mathrm{mg} /$ day who showed only the methylated band pre-treatment, but both bands after treatment, which correlated with re-expression of MGMT. 2C is a $50 \mathrm{mg} /$ day patient which failed to demethylate the DAPK gene and therefore lacked expression. 2D represents the distribution of informative cases. From the 128 genes/cases, II 6 were RT-PCR positive regardless of the methylation status, hence were not informative. In the remaining 12 cases, nine demethylated and reexpressed the gene.

agent in a clinical trial involving cancer patients could proceed with no major concerns regarding unexpected toxicity and long-term side effects aside of its known capacity to induce a lupus-like condition [35]. Evaluation of tumor DNA demethylating agents in patients bearing solid tumors is troublesome due to the need of repeated tumor sampling. Cervical cancer is easily accessible for
A

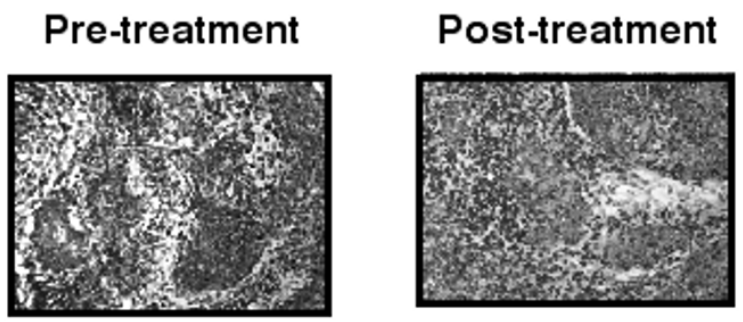

B

TUMOR FRAGMENTS

$\frac{1}{M U} \frac{2}{M U} \frac{3}{M U} \frac{4}{M U}{ }_{\text {DAPK }}$

Figure 3

3A. Photomicrography of a representative set of pre and post-treatment tumor biopsies showing that the malignant component represents almost the half of the tumor. 3B. Methylation analysis of the DAPK gene in the four fragments of the tumor biopsy of an untreated cervical cancer patient. Despite all fragments contained different proportions of malignant cells and stroma the four samples show methylated and unmethylated bands.

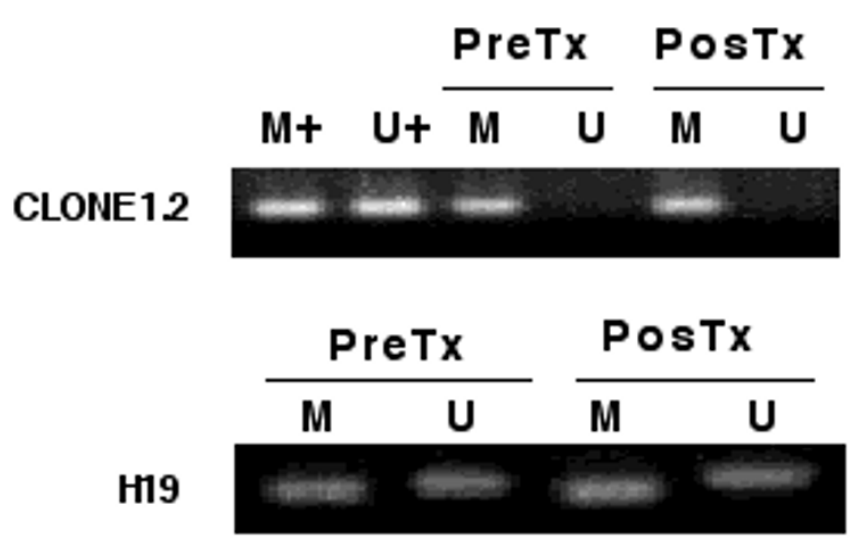

Figure 4

DNA methylation analysis obtained from peripheral mononuclear cells of genes "imprinted or normally methylated". Clone I.2 remained methylated in all cases whereas for the imprinted $\mathrm{HI} 9$ gene, the pattern of $U$ and $M$ alleles did not change. 

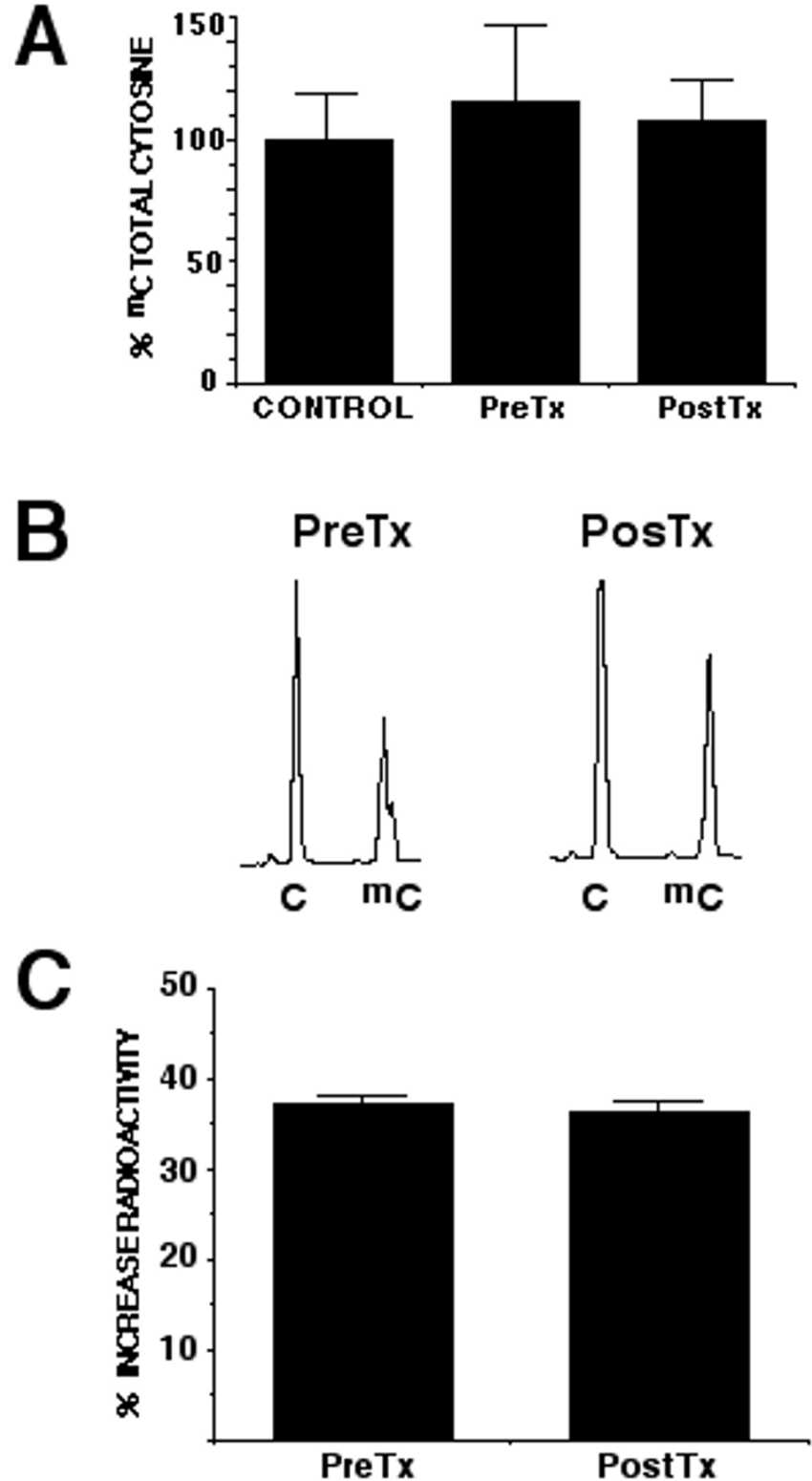

Figure 5

5A. Capillary electrophoretic analysis of global methylation. Relative methylation showed no variation in percentage of $\mathrm{mC}$ after treatment (37.3\% versus $36.3 \%$ ). 5B is a electropherogram showing the separation of $C$ and ${ }^{m} C$. $\mathbf{5 C}$ is the percent increase in radiolabeled incorporation pre and posttreatment as compared to the control of undigested DNA.

repeated tumor sampling and thus we chose to study patients with newly diagnosed cervical cancer. In order to avoid treatment delay in the studied group, we scheduled the present study between the date of diagnosis and the beginning of chemoradiation. In addition, three recent publications have consistently shown a number of tumor suppressor genes to be methylated in primary cervical tumors [36-38]. Our results demonstrate that 70\% of the pretreatment samples analyzed had at least one gene methylated, and all 16 patients had at least one methylated gene. The methylation frequency ranged from 3/16 (19\%) to $16 / 16(100 \%)$ for p16 and DAPK genes respectively. (Figure 1A). Despite the fact that our global gene methylation frequency is remarkably similar to the frequencies reported by other authors [36-38] who found $86 \%, 74 \%$ and $79 \%$ respectively, we encountered differences in individual gene methylation frequencies which most likely stem from the different patient populations analyzed such as invasive versus pre-invasive disease, tumor histologies, and clinical stages (Table 6). Nevertheless, our results and those obtained in other studies as shown in Table 6, suggest that cervical cancer is a good tumor model to evaluate the effect of DNA demethylating agents upon a small number of individual genes found consistently methylated in high proportion. As expected, there were genes "fully" unmethylated or "fully" methylated but we also observed cases showing both methylated and unmethylated bands. Such ambiguous methylation pattern as evaluated by methylation-specific PCR is commonly observed when patient tumor samples are studied which probably results from certain degree of normal tissue/cell biopsy contamination. This may rise concerns on whether the demethylating effect showed post-treatment is consequence of the treatment and not due tumor heterogeneity, however, in all pretreatment and post-treatment biopsies the major component of the tumor was malignant cells (Figure 3A); On the other hand, if demethylation were the result of chance alone we would expect to have cases in both directions, that is, methylated tumors that demethylated, and demethylated tumors that methylated. The latter never occurred, which strongly supports that the demethylating effect was caused by hydralazine. To gain further insight into the issue of tumor heterogeneity, we multi-sampled a tumor and submitted to methylation analysis each of the tumor fragments containing malignant cells. As shown in Figure 3B, there were no changes in the pattern of methylation in the four separate tumor areas of the tumor. This result strongly supports the observation that demethylation is an effect of hydralazine.

Hydralazine is considered a safe drug with hypertension and hearth failure dosing ranging from $50 \mathrm{mg}$ day to 400 $\mathrm{mg} /$ day [33,34]. However, higher doses produce symptomatic side effects mainly derived from its cardiovascular effects. Based on this, we felt important to determine the lowest possible dose that induced DNA demethylation to be used in future clinical trials. In the present study we demonstrate that at a dose range between $50 \mathrm{mg}$ and $150 \mathrm{mg}$ a day for 10 days, hydralazine 
Table 6: Frecuency of promoter methylation of individual genes (\%).

\begin{tabular}{lccccccccc}
\hline & APC & ER & FHIT & GSTPI & MGMT & PI6 & RARB & DAPK & ANY \\
\hline This study & 94 & 25 & 88 & 88 & 81 & 19 & 62 & 100 & 70 \\
Narayan (ref 35) & II & - & 11 & - & 5 & 8.5 & 29 & 45 & 86 \\
Virmani (ref 34) & - & - & 32 & 21 & 26 & 42 & 26 & - & 74 \\
Dong (ref 36) & 32 & - & - & - & 8 & 30 & - & 51 & 79 \\
\hline
\end{tabular}

not only induces gene demethylation in roughly half the evaluated gene/tumors, but we also observed re-expression in two-thirds of the informative cases. However, due to the limited sample size of this study we could not establish whether the effectiveness of this demethylating agent is gene or patient-dependent.

At the present time there is limited information regarding cancer treatment efficacy, demethylating and gene reexpressing profiles of the various DNA demethylating agents in the clinical setting. There are three clinical trial reports evaluating 5-aza-2'-deoxycytidine. Two of these were performed in patients with myelodysplasic syndrome and relapsed leukemia patients. Daskalakis et al., using the quantitative assay Ms-SNuPE found basal hypermethylation of p15 gene in $15 / 23$ patients $(65 \%)$ which decreased in nine of 12 patients sequentially analyzed after at least a course of low-dose decitabine. As expected, reactivation of the $\mathrm{p} 15$ protein expression was found in bone marrow biopsies of four out of eight patients analyzed in this study. Interestingly, response (3 CR) was observed on all nine patients in whom p15 gene demethylation occurred [39]. More recently, a phase I study with escalating doses of decitabine $\left(5,10,15\right.$ or $20 \mathrm{mg} / \mathrm{m}^{2} \mathrm{IV}$ over 1 hour daily, 5 days a week for two consecutive weeks) found responses in $11 / 18$ patients $(61 \%)$, however, no significant decline in p15 methylation after treatment with decitabine regardless of the response was observed. Moreover, in the three patients that showed $>50 \%$ demethylation, evaluated by the COBRA assay there was no response. Authors speculated on the poor sensitivity of this technique to explain their results [40]. Evaluation of these nucleoside analogs in solid tumors has also shown inconsistent results. Aparicio et al., reported a phase I study using 5-aza-2'-deoxycytidine in patients with advanced solid tumors using escalating doses of $20,30,40 \mathrm{mg} / \mathrm{m}^{2}$ using a 72 -hour continuous infusion every 28 days. The quantitative Methyl-Light reaction was used to evaluate changes in promoter methylation in 19 genes but no consistent evidence of gene demethylation was documented despite grade 4 neutropenia was found in almost a third of the patients. This latter finding argues against its use as DNA demethylating agent in solid tumors because despite such toxicity the steady-state levels reached during the study $(0.1-0.2 \mu \mathrm{M})$ are below the levels needed in vitro to demethylate gene promoters [41]. On the other hand, a number of genes showed increased methylation which could be derived from the cytotoxicity of this nucleoside analog. It is wellknown that most of the cytotoxic agents lead to an increase in DNA methylation in vitro and in cancer patients [42].

Among the non-nucleoside demethylating agents, MG98, a DNMT1 antisense oligonucleotide, has been tested in a phase I study to treat solid tumors. In contrast to the studies discussed above no attempt was done to evaluate gene methylation in tumors although DNMT1 mRNA levels were investigated in peripheral blood cells; no consistent decrease was observed [25].

Our results demonstrate that hydralazine is quite promising in regards to its gene demethylating and tumor suppressor gene reactivating activities without significant side effects. It is noteworthy that a dose-effect level in the frequency of demethylation was not observed. A pharmacokinetic correlation analysis would have been useful for the interpretation of these findings, nonetheless, the pharmacokinetics of this drug is relatively well-known and some assumptions can be made. After a single $1 \mathrm{mg} / \mathrm{kg}$ oral dose and after the fifth $1 \mathrm{mg} / \mathrm{kg}$ dose given every 12 hours, the peak concentrations achieved are in the range of 0.12 $1.31 \mu \mathrm{M}$ and $0.10-1.39 \mu \mathrm{M}$ respectively and AUC values range between: $4.0-30.4$ and 3.2-38.5 $\mu \mathrm{M}$-minute, respectively [43]. These concentrations were likely achieved in our patients at the doses used which are close to the concentrations needed to achieve gene demethylation and re-expression in vitro [26]. It is not clear why we observed such variable gene demethylation rates irrespective of the doses used, this may be the result of the small number of patients studied as well as the additional variability imposed by the acetylator phenotype which may vary from 30 to $70 \%$ according to some studies performed in Latin American Hispanic populations [44].

After years characterizing the role of DNA methylation in cancer, it has become clear that both hypermethylation and hypomethylation are by their own cancer causative or at least cancer promoting, in animal models. This has led to consider the use of demethylating agents for cancer 
treatment a two-edge sword [45]. Such consideration is debatable as the profound DNA demethylation levels achieved in animal models can be hardly pharmacologically reproduced in patients. The present study demonstrates that hydralazine at the doses used not only does not demethylate genes which are "normally methylated" such as $\mathrm{H} 19$ and clone 2.1 but also fails to produce global DNA demethylation as evaluated by capillary electrophoresis which is a powerful and accurate method to quantitate methylated and unmethylated cytosines [46], and by cytosine extension assay which is also a sensitive method to underscore abnormal methylation patterns [31]. We can only speculate on the nature of these findings. At the individual gene level, a plausible explanation could be that certain "normally methylated" genes could lie within a milieu prone to rapid re-methylation and/or that certain genes have higher "availability" of the elements that compose the methylation machinery, therefore the demethylating agent would fail to produce demethylation of these sequences at least at a detectable levels by the current methods of analysis. This view is supported by the reporting that in mice 5-azacytidine does not change the methylation status of H19 [47]. In regard to global DNA methylation changes most likely is just a matter of dose as we have in vitro evidence that hydralazine produces global DNA hypomethylation in MCF-7 cells as evaluated by the same methods here used. Alternatively, changes in global ${ }^{\mathrm{m}} \mathrm{C}$ content induced by hydralazine are not sufficient to be detected by the methods we used.

\section{Conclusion}

In conclusion, hydralazine used at standard doses for the treatment of cardiovascular conditions is an effective demethylating and tumor suppressor gene transcriptional reactivator causing no decrease in DNA $\mathrm{mC}$ content for solid tumors. Our results are in agreement with those reported by Chan et al., who found substantial degrees of demethylation at all latent and lytic Epstein-Barr virus promoters examined by methylation-specific PCR in nasopharyngeal cancer patients treated with 5-azacytidine [48]. A phase II clinical study using hydralazine in combination with standard cytotoxic chemotherapy is being planned as proof of concept that the reactivation of tumor suppressor genes silenced by DNA methylation increases chemotherapy efficacy in solid tumors.

\section{Competing interests}

The author(s) declare that they have no competing interests.

\section{Authors' contributions}

P Z, B S-P, E P-C, C T-B, L TC, and A C-B performed the methylation analysis and gene expresión experiments; $\mathrm{LC}$ cared for the patients; AR-V and KS performed the capil- lary electrophoresis analysis; EA and GC critically read and contributed to the discussion; $\mathrm{J} \mathrm{C-V}$, performed the pathological analysis; and A D-G conceived the study and wrote the manuscript.

\section{Acknowledgements}

This work was supported by CONACyT grants: SALUD-2002-C0I-6579, AVANCE COI-294, and by Psicofarma S.A. de C.V. Mexico.

\section{References}

I. Robertson KD: DNA methylation, methyltransferases and cancer. Oncogene 200I, 20:3139-55.

2. Pradhan S, Bacolla A, Wells RD, Roberts RJ: Recombinant human DNA (cytosine-5) methyltransferase.I. Expression, purification, and comparison of de novo and maintenance methylation. J Biol Chem 1999, 274:33002-10.

3. Beard C, Li E, Jaenisch R: methylation activates Xist in somatic but not in embryonic cells. Genes Dev 1995, 9:2325-34.

4. Li E, Beard C, Jaenisch R: Role for DNA methylation in genomic imprinting. Nature 1993, 366:362-5.

5. Leonhardt $\mathrm{H}$, Page AW, Weier HU, Bestor TH: A targeting sequence directs DNA methyltransferase to sites of DNA replication in mammalian nuclei. Cell 1992, 71:865-73.

6. Chuang LS, lan HI, Koh TW, Ng HH, Xu G, Li BF: Human DNA(cytosine-5) methyltransferase-PCNA complex as a target for P2 I WAFI. Science 1997, 277: 1996-2000.

7. Okano M, Bell DW, Haber DA, Li E: DNA methyltransferases Dnmt3a and Dnmt3b are essential for de novo methylation and mammalian development. Cell 1999, 99:247-57.

8. Okano $\mathrm{M}, \mathrm{Xie} \mathrm{S}$, $\mathrm{Li}$ E: Dnmt2 is not required for de novo and maintenance methylation of viral DNA in embryonic stem cells. Nucleic Acids Res 1998, 26:2536-40.

9. Tate PH, Bird AP: Effects of DNA methylation on DNA-binding proteins and gene expression. Curr Opin Genet Dev 1993, 3:226-31.

10. Nan X, Campoy FJ, Bird A: MeCP2 is a transcriptional repressor with abundant binding sites in genomic chromatin. Cell 1997 , 88:47I-8I.

1I. Rountree MR, Bachman KE, Baylin SB: DNMTI binds HDAC2 and a new co-repressor, DMAPI, to form a complex at replication foci. Nature Genet 2000, 25:269-77.

12. Nan X, Ng HH, Johnson CA, Turner BM, Eisenman RN, Bird A: Transcriptional repression by the methyl-CpG-binding protein MeCP2 involves a histone deacetylase complex. Nature 1998, 393:386-9.

13. Bird A: The essentials of DNA methylation. Cell 1992, 70:5-8.

14. Clark SJ, Melki J: DNA methylation and gene silencing in cancer: which is the guilty party? Oncogene 2002, 21:5380-7.

15. Antequera $F$, Bird A: Number of CpG islands and genes in human and mouse. Proc Natl Acad Sci USA 1993, 90: I 1995-9.

16. Baylin SB, Herman JG: DNA hyper methylation in tumorigenesis: epigenetics joins genetics. Trends Genet 2000, 16:168-74.

17. Santini V, Kantarjian HM, Issa JP: Changes in DNA methylation in neoplasia: pathophysiology and therapeutic implications. Ann Intern Med 200I, I 34:573-86.

18. Bigey P, Knox JD, Croteau S, Bhattacharya SK, Theberge J, Szyf M: Modified oligonucleotides as bona fide antagonists of proteins interacting with DNA. Hairpin antagonists of the human DNA methyltransferase. J Biol Chem 1999, 274:4594-606.

19. Lantry LE, Zhang Z, Crist KA, Wang Y, Kelloff G], Lubet RA, You M: 5-Aza-2'-deoxycytidine is chemopreventive in a 4-(methylnitrosamino)-I-(3-pyridyl)-I-butanone-induced primary mouse lung tumor model. Carcinogenesis 1999, 20:343-6.

20. Covey JM, Zaharko DS: Comparison of the in vitro cytotoxicity (LI2I0) of 5-aza-2'-deoxycytidine with its therapeutic and toxic effects in mice. Eur J Cancer Clin Oncol 1985, 2 1: 109-1 I7.

21. Wu J, Issa JP, Herman J, Bassett DE, Nelking BD, Baylin SB: Expression of an exogenous eukaryotic DNA methyltransferase gene induces transformation of NIH3T3 cells. Proc Natl Acad Sci USA 1993, 90:8891-5.

22. Ramchandani S, MacLeod AR, Pinard M, Von Hofe E, Szyf M: Inhibition of tumorigenesis by a cytosine-DNA methyltransferase, 
antisense oligodeoxynucleotide. Proc Natl Acad Sci USA 1997, 94:684-9.

23. Goffin J, Eisenhauer E: DNA methyltransferase inhibitors-state of the art. Ann Oncol 2002, 13:1699-7|6.

24. Lyons J, Bayar E, Fine G, McCullar M, Rolens R, Rubinfeld J, Rosenfeld $C$ : Decitabine: development of a DNA methyltransferase inhibitor for hematological malignancies. Curr Opin Investig Drugs 2003, 4: I442-50.

25. Stewart DJ, Donehower RC, Eisenhauer EA, Wainman N, Shah AK, Bonfils C, MacLeod AR, Besterman JM, Reid GK: A phase I pharmacokinetic and pharmacodynamic study of the DNA methyltransferase I inhibitor MG98 administered twice weekly. Ann Oncol 2003, 14:766-74.

26. Segura-Pacheco B, Trejo-Becerril C, Perez-Cardenas E, Taja-Chayeb L, Mariscal I, Chavez A, Acuna C, Salazar AM, Lizano M, DuenasGonzalez A: Reactivation of tumor suppressor genes by the cardiovascular drugs hydralazine and procainamide and their potential use in cancer therapy. Clin Cancer Res 2003, 9:1596-603.

27. Angeles $E$, Vazquez-Valadez $V H$, Vazquez-Valadez $O$, VelazquezSanchez AM, Ramirez A, Martinez L, Diaz-Barriga S, Romero-Rojas A, Cabrera G, Lopez-Castañares R, Duenas-Gonzalez A: Computational studies of I-Hydrazinophtalazine (Hydralazine) as antineoplastic agent. Docking studies on methyltransferase. Lett Drug Design Discov 2005 in press.

28. Herman JG, Graff JR, Myohanen S, Nelkin BD, Baylin SB: Methylation-specific PCR: a novel PCR assay for methylation status of CpG islands. Proc Natl Acad Sci USA 1996, 93:982I-6.

29. Strichman-Almashanu LZ, Lee RS, Onyango PO, Perlman E, Flam F, Frieman MB, Feinberg AP: A genome-wide screen for normally methylated human CpG islands that can identify novel imprinted genes. Genome Res 2002, I 2:543-54.

30. Sandoval Guerrero K, Revilla Vazquez A, Segura-Pacheco B, DuenasGonzalez A: Determination of 5-methyl-cytosine and cytosine in tumor DNA samples of cancer patients. Electrophoresis 2005, 26: 1057-62.

31. Pogribny I, Yi P, James SJ: A sensitive new method for rapid detection of abnormal methylation patterns in global DNA and within CpG islands. Biochem Biophys Res Commun 1999, 262:624-8.

32. Kirsten R, Nelson K, Kirsten D, Heintz B: Clinical pharmacokinetics of vasodilators. Part II. Clin Pharmacokinet 1998, 35:9-36.

33. Magee LA, Cham C, Waterman EJ, Ohlsson A, von Dadelszen P: Hydralazine for treatment of severe hypertension in pregnancy: meta-analysis. BMJ 2003, 32:7955-60.

34. Klein L, O'Connor CM, Gattis WA, Gattis WA, Zampino M, de Luca L, Vitarelli A, Fedele F, Gheorghiade M: Pharmacologic therapy for patients with chronic heart failure and reduced systolic function: review of trials and practical considerations. Am J Cardiol 2003, 9: I8F-40F.

35. Yung R, Chang S, Hemati N, Johnson K, Richardson B: Mechanisms of drug-induced lupus. IV. Comparison of procainamide and hydralazine with analogs in vitro and in vivo. Arthritis Rheum 1997, 40:1436-43.

36. Virmani AK, Muller C, Rathi A, Zoechbauer-Mueller S, Mathis M, Gazdar AF: Aberrant methylation during cervical carcinogenesis. Clin Cancer Res 200I, 7:584-9.

37. Narayan G, Arias-Pulido H, Koul S, Vargas H, Zhang FF, Villella J, Schneider A, Terry MB, Mansukhani M, Murty VV: Frequent promoter methylation of CDHI, DAPK, RARB, and HICI genes in carcinoma of cervix uteri: Its relationship to clinical outcome. Mol Cancer 2003, 2:24-30.

38. Dong SM, Kim HS, Rha SH, Sidransky D: Promoter hypermethylation of multiple genes in carcinoma of the uterine cervix. Clin Cancer Res 2001, 7:1982-6.

39. Daskalakis M, Nguyen TT, Nguyen C, Guldberg P, Kohler G, Wijermans $\mathrm{P}$, Jones PA, Lubbert M: Demethylation of a hypermethylated PI5/INK4B gene in patients with myelodysplastic syndrome by 5-Aza-2'-deoxycytidine (decitabine) treatment. Blood 2002, 100:2957-64.

40. Issa JP, Garcia-Manero G, Giles FJ, Mannari R, Thomas D, Faderl S, Bayar E, Lyons J, Rosenfeld CS, Cortes J, Kantarjian HM: Phase I study of low-dose prolonged exposure schedules of the hypomethylating agent 5-aza-2'-deoxycytidine (decitabine) in hematopoietic malignancies. Blood 2004, 103:1635-40.
41. Aparicio A, Eads CA, Leong LA, Laird PW, Newman EM, Synold TW, Baker SD, Zhao M, Weber JS: Phase I trial of continuous infusion 5-aza-2'-deoxycytidine. Cancer Chemother Pharmacol 2003, 5I:23I-9.

42. Nyce JW: Drug-induced DNA hypermethylation: a potential mediator of acquired drug resistance during cancer chemotherapy. Mutat Res 1997, 386: I53-6I.

43. Ludden TM, McNay JL Jr, Shepherd AM, Lin MS: Variability of plasma hydralazine concentrations in male hypertensive patients. Arthritis Rheum 1981, 24:987-93.

44. Dipierri JE, Alfaro E, Bejarano IF, Etchart AA: Acetylator phenotypes: allele frequency in northwestern Argentina and review of acetylator distribution in the Americas. Hum Biol 1998, 70:959-64.

45. Feinberg AP, Tycko B: The history of cancer epigenetics. Nat Rev Cancer 2004, 4: 143-53.

46. Stach D, Schmitz OJ, Stilgenbauer S, Benner A, Dohner H, Wiessler M, Lyko F: Capillary electrophoretic analysis of genomic DNA methylation level. Nucleic Acids Res 2003, 3 I:E2.

47. Hu JF, Nguyen PH, Pham NV, Vu TH, Hoffman AR: Modulation of Igf2 genomic imprinting in mice induced by $\mathbf{5}$-azacytidine, an inhibitor of DNA methylation. Mol Endocrinol 1997, II:I89|-8.

48. Chan AT, Tao O, Robertson KD, Flinn IW, Mann RB, Klencke B, Kwan WH, Leung TW, Johnson PJ, Ambinder RF: Azacitidine induces demethylation of the Epstein-Barr virus genome in tumors. J Clin Oncol 2004, 22:1373-8I.

\section{Pre-publication history}

The pre-publication history for this paper can be accessed here:

http://www.biomedcentral.com/1471-2407/5/44/prepub
Publish with Biomed Central and every scientist can read your work free of charge

"BioMed Central will be the most significant development for disseminating the results of biomedical research in our lifetime. "

Sir Paul Nurse, Cancer Research UK

Your research papers will be:

- available free of charge to the entire biomedical community

- peer reviewed and published immediately upon acceptance

- cited in PubMed and archived on PubMed Central

- yours - you keep the copyright

Submit your manuscript here:

http://www.biomedcentral.com/info/publishing_adv.asp
BioMedcentral 